\title{
Safety Perception of Turkish and European Passengers in Turkish Airports: A Cross-National Comparison
}

\author{
Nuriye Güreș (Asst. Prof. Dr.) \\ Mustafa Kemal University / School of Civil Aviation \\ Sarkkonak mah. 457. sok. No: 2 Karaağaç 31217, İskenderun, Hatay, Turkey
}

Tel: 90-326-641-6510Ｅ-mail: ngures98@gmail.com

Halil Demirer (Asst. Prof. Dr.)

Mustafa Kemal University / School of Civil Aviation

Sarkkonak mah. 457. sok. No: 2, Karaağaç 31217, İskenderun, Hatay, Turkey

Tel: 90-326-641-6510 E-mail: demirerhali1@gmail.com

Şenkan Aldemir (Asst. Prof. Dr.)

Mustafa Kemal University / Faculty of Economics and Administrative Sciences

Tayfur Ata Sokmen Campus Antakya, Hatay, Turkey

Tel: 90-326-245-5845 / 1238 E-mail: senkan.aldemir@gmail.com

Lutfu Tayfur (Ph.D.)

Customs Office of Antakya, Antakya, Hatay, Turkey

E-mail: ltayfur@yahoo.com

Seda Arslan (Res. Asst.) (Corresponding author)

Mustafa Kemal University / School of Civil Aviation

Sarkkonak mah. 457. sok. No: 2, Karaağaç 31217, İskenderun, Hatay, Turkey

Tel: 90-326-641-6510Ｅ-mail: sedaarslan14@yahoo.com

Received: November 26, $2010 \quad$ Accepted: December 25, $2010 \quad$ doi:10.5539/ijbm.v6n4p90

This research was supported and funded by TUBITAK (The Scientific and Technological Research Council of Turkey)

\begin{abstract}
This research primarily aimed to illustrate the national differences of passengers regarding their perceptions of Turkish airport safety. Secondly, airport safety perceptions by some other consumer characteristics such as demographics, flight characteristics, fairness perception and satisfaction from airport services were tried to be revealed.

The research had a between-groups comparison design of data obtained in a one time measurement of the field. The predictions were tested in a sample of 911 Turkish and, 595 European passengers in Turkish airports. Data collecting method used in the study was 7-point Likert type self-report questionnaire filled by the respondents on voluntary basis in a categorical and random sampling. Independent sample t-tests, one-way Analysis of Variance ANOVA were used to reveal group differences in safety perceptions by nationalities and some other consumer
\end{abstract}


characteristics.

Significant differences among nationalities were found regarding safety perceptions. Meaningful differences were found by flight frequency, fairness perception and satisfaction degree from the services at airport. Study gains importance as being of the first time investigation of the differences between European and Turkish passengers about Turkish airports regarding safety perception.

Keywords: Airport passenger, Safety perception

\section{Introduction}

The number of people using airways for travelling to Turkey has been increasing gradually each year. Airline companies and the volume of flights have increased due to governmental incentives supporting civil air transportation. This resulted in low ticket prices and travellers have given preference to air transportation more than before. In order to evaluate this potential effectively, besides the airlines, the airports which have a national value and significance for country image should be analyzed. So in this study, the airports which are static elements in flight have been included and searched.

Safety perception in the literature has been commonly examined from crime and safety point of view (Brunt, Mawby and Hambly, 2000; Milman and Bach, 1999; Sonmez and Graefe, 1998) where safety and security of tourists is a prerequisite for tourists' destination choice is a basic finding. Although the OECD data on Turkey shows that less crime to population ratio than the OECD countries on average during 1992 and 2004 period (http://www.oecd.org/dataoecd/26/40/38785295.htm). This data may not necessarily indicate that Turkish airports being perceived as safe places.

Especially after $9 / 11$ attacks, airport security has come into prominence in the whole world. Considerable time and money have been spent developing the new security procedures. So, understanding the passengers perceptions with increased security measures, their fairness perceptions and satisfaction with the airport experience has become very important from managerial and marketing perspectives (Sindhav et al, 2006). In tourism context, there are evidences in some studies that safety perception effects people's choices and behaviors (Kinnaird, 1996; Mansfeld, 1992) in which the antecedents of safety was relatively less surveyed (Rountree, 1996; Blum and Feltes, 1987).

Furthermore, while many researches have been made about airline companies which have intensive competition, researches about airports are relatively less. At the same time, while the topics as customer satisfaction, safety and fairness perception of passengers have precedence in studies related to airline companies, airports have been neglected in this manner or the problems have not been considered with customer orientation. So in this study, the safety perception of European passengers and its comparison with Turkish passengers have been searched because of the importance for Turkey as a country in the process of entrance into the European Union.

\section{Safety perception}

The airport industry is changing rapidly. Today's air travellers have meaningful choices among airports and there is an increasing urgency among airport managements to differentiate themselves by meeting the needs of customers better than the competition (Fodness and Murray, 2007). While passengers' airport safety perception is only one of several variables (e.g. routes, scheduling, location and prices) that contribute to overall airport attractiveness, it is nevertheless an important variable because of the increasing importance of a customer orientation to competitive advantage in this industry.

Demand for air transport slowed in recent years because of the global economic downturn. Following the events of September 11, 2001, airports experienced dramatic declines in passenger traffic especially with US airports suffering the greatest losses (Fodness and Murray, 2007). After this event, many studies have been made to understand the effects of $9 \backslash 11$ and perceptions of passengers about the airports in different parts of the world. Some of these studies can be summarized as follows:

Goodrich (2002) researched the impacts of the September 11 terrorist attacks on the travel and tourism industry in USA. After 9\11, the tourism industry in Amerika was severely affected, with immediate declines in airline passenger loads of $50 \%$ and more, and similar declines in hotel occupancy. From hence, it's understood that safety perception of passengers is a very important factor that can be the reason of drastic crisis in civil aviation and tourism sector.

Russell and Preston (2004) made interviews with airline and security employees and public information was used to examine the real and perceived outcomes of public policy reactions to the terrorist attacks of September 11. Study results showed that governments and airlines were not well prepared for terrorist attacks, a fact that 
was well known to insiders but not widely known to the public. Many of the illusions of security that preceeded the attacks were exposed by discussions and policy reactions following September 11.

Tourist safety perception in Cape Town as a city with high volume of criminal records was surveyed (George, 2003). Carr (2001) studied safety and danger in London as a domain that was methodologicaly deconstructed into five separate, but interrelated parts as safety, threatfulness, vulnerability, relaxing and perceived risk. Gender differences as an antecedent in perception of danger and safety in public spaces were studied by various researches (Rountree,1996; Smith, 1987; Mehta and Bondi, 1999).

\section{Fairness Perception of Passengers}

Justice theory constitutes a basis for fairness in human social interactions both for exchange and workplace environment. Justice theory have three types of justice as distributive, procedural and interactional. Theory having four types of justice explains workplace fairness mostly by distributive justice. But in exchange environments such as customer's service experience, generally the interpersonal and informational justice types are found appropriate. Fairness in this study was located from this point of view. This point of view has its basis in the intersection of social, psychological and marketing literature.

Fairness perceptions of air passengers were examined by Colquitt (2001) and Sindhav and others (2006). The results of Sindhav and others' study indicated that fairness perception has significant effects on passenger satisfaction. Besides, contradicting to previous research findings that the fairness perception on procedures had the largest effect on passenger satisfaction. Discrimination in the delivery of the airport service is not appreciated. This took place in the report about the airports in which discrimination among passengers on security procedures regarding their ethnicity, nationality and religious roots.

Many researchers have found that fairness influence satisfaction (Austin, McGinn, and Susmilch 1980; Goodwin and Ross 1992; Messick and Sentis 1983; Oliver 1997; Swan and Oliver, 1991; Szymanski and Henard 2001; Yoda, 2007). Thus any parameters effecting fairness perception would automatically have effect in the changes in passenger satisfaction as well. That is why in this study these two constructs were both taken into consideration.

\section{Passenger Satisfaction At Airport}

Customer satisfaction is a wide assesment based on total purchase and consumption experience in time related to a good or service (Anderson and others, 1994). Customer satisfaction is the result of comparison between expectancies and the perceived performans of consumers' relevant aspects in all stages of the consumption experience (Bassi and Guido, 2006). Determining customer satisfaction has an important role in distributing the services effectively. Having knowledge with the level of customer satisfaction and using this knowledge in application provide the managers competitive advantage as the result of product differentiation, keeping customers and positive word of mouth communication (Yüksel and Rimmington, 1998).

Gkritza and others (2006) tried to uncover factors that determine passenger satisfaction at security screening points. Their findings showed that wait times at security screening points were significant determinants of passenger satisfaction. Moreover, according to the results the determinants of customer satisfaction were not stable over time and there were many other factors come into play. They suggest that further refinements in airport screening procedures should be made and careful consideration to the factors underlying passenger satisfaction and wait times should be considered.

Martin - Cejas (2006) searched the relationship between passenger satisfaction and the level of service established in a check-in service at Canaria airport through a linear programming model. Research results showed that average waiting time and crowding level for airport facilities are two relevant aspects in quality perception and satisfaction of passengers. For regular flights, Canaria airport showed an excellent check-in facility service level, however for charter flights the level of service has to be improved.

Correia and Wirasinghe (2007) conducted a passenger survey at Sao Paulo International Airport in Brazil. They used qualitative survey data and derived quantitative values for passenger perceptions of service. At the end of the study, processing time, waiting time and space available per person have been determined as the main elements of service level given at the airport.

In previous literature, Nebeker and others (2001) examined whether employee satisfaction is linked to organizational performance and customer satisfaction. Satisfaction data from 12842 employees at 60 airport stations and performance data of those stations were used to explore the relationship between satisfaction levels and airport station performance. Results indicated that traffic volume and some dimensions of employee satisfaction are related to the performance. In addition, employee affective commitment and airport traffic 
volume interact in accounting for customer satisfaction.

Paternoster states that excellent customer service is the synergy created when an airport's ability to exceed its customers' needs and expectations consistently matches its customers' perception that their needs and expectations are well met. Also if airport management takes a strategic and holistic approach to customer service and aiport branding, customer satisfaction with the airport experience can be significantly improved and aiport net revenues can be tracked to show a direct relationship with increased customer satisfaction (2008). So passengers' satisfaction about the airports is very important for airport managements.

The satisfaction in the airport was evaluated from three main points of view; waiting time, processing time and and availability of space per person (Correia and Wirasinghe, 2007). These points were included in the criterion developed by Airport Council International (ACI) to evaluate the overall satisfaction about the services in the airport.

\section{Research Design}

In the design of the research; age, gender, educational level, average monthly income, nationality, flight frequency in a year, flight objective, fairness perception and, satisfaction level were determined as categorical variables for making comparison groups. The research aimed to explore the association among national and other characteristics of passengers such as demographics, fairness perception and satisfaction level from airport services.

\section{Methodology}

\subsection{Sample}

Tourism statistics regarding nationalities provided by Turkish Statistical Institute (TUIK) were taken as the basis for the population of the survey. The distribution of 10 million European passengers regarding nationalities in percentages as follows were taken into consideration in sampling: Germany \% 39, England \% 12, Netherland \% 12 , France $\% 5$, Austria $\% 4$, Belgium $\% 4$, Sweden \% 4, Denmark $\% 2$, Italy $\%$ 2, Poland $\% 1$, Spain $\% 0.8$, Finland $\% 0.4$, Greece $\% 0.4$, Ireland $\% 0.2$. On the other hand, the data obtained from the sources of the same statistical authority denotes that the population of Turkish passengers using Turkish airports has been 32 million in a year. Table (1) presents the demographic characteristics of the sample.

The hypotheses were tested on a sample of 595 European and 911 Turkish passengers who evaluated Turkish Airports. Respondents voluntarily participated to the survey. Self reported questionnaire forms were filled in by the passengers waiting in both the domestic and international lines area of the airports in a face to face interview manner. The rate of valid forms returned was $75 \%$.

\subsection{Measures}

The scales used in the survey were translated and implemented in Turkish and three European languages (English, German and French). In order to test the reliability of the scales, 80 filled forms for European and 110 filled forms for Turkish sample were used for pilot study to test the scales that will be included in the survey.

The safety perception of the passengers were measured by a composite scale that has been developed and tested in both sample groups. The items were gathered from the scale developed for measuring tourists' safety perception in London by Carr (2001) and the scale developed for measuring tourist safety perception in Cape Town city by George (2003). The new scale consisted 7 items. One of the items was as "This airport is a safe place against threats of all sorts." All of the items were scaled as ( $1=$ strongly disagree) ... ( $7=$ strongly agree). The Cronbach alpha reliability scores of the scale in Turkish group was $\alpha=0.85$ and in European group $\alpha=0.89$ (Nunnally, 1978).

Fairness perceptions of air passengers was meausured using the scale $(\alpha=.81)$ developed by Colquitt (2001) and tested by Sindhav (2006). The scale consisted 15 items. One of the items was as "Security operations are carried out equally at this airport." All of the statements were scaled as $(1=$ strongly disagree) ... ( $7=$ strongly agree).

The satisfaction in the airport was evaluated from three main points of view; waiting time, processing time and and availability of space per person (Correia and Wirasinghe, 2007). These points were include in the criterion developed by Airport Council International (ACI) to evaluate the overall satisfaction about the services in the airport was entirely adopted and revised for reliability considerations into this survey. The form called as Airport Voluntary Commitment on Air Passenger Service is a 14 item scale included statements such as "This airport does not meet needs of disabled or older passengers." The scale in total had an appropriate value of cronbach alpha $(\alpha=0.85)$ and was found to be reliable (http://www.aci-europe.org).

Finally the personal profile such as age, gender, educational level, average monthly income and nationality were 
asked. Moreover the flight experiences of the passengers such as flight objective and flight frequency in a year were surveyed.

\subsection{Procedure}

Data collecting method used in the study was self-report questionnaires filled by the respondents. Mediterranean tourism seasons were taken as the basis of survey phasing. Low and peak seasons have reflection on airports as low and high passenger traffic. Survey was executed in two phases regarding this perspective. In addition, two additional phases were included as weekdays and weekends to insure the heterogeinty in the samples. The domestic and international flight areas in the airports were used to have the questionnaires filled in a convenience manner. Total number of valid forms obtained was 595 for European passengers and 911 for Turkish passengers. Research model included safety perception of passengers in airports and the degree of satisfaction and fairness perceptions about airport services. Control variables of the study were age, gender, educational level, average monthly income, nationality, flight objective and flight frequency in a year. Independent sample of t-test and one-way analysis of variance (ANOVA) techniques were used to examine the differences among comparison groups.

\section{Analyses and Results}

\subsection{Nationalities on Safety Perceptions}

Table (2) indicates that there is a significant difference between the means of European and Turkish passengers regarding safety perception about Turkish airports $(\mathrm{p}<0.05)$. It is evident from the means of the nationality groups that the Turkish passengers feel safer than European passengers.

\subsection{Flight Frequencies on Safety Perceptions}

Table (3) indicates that there is a significant difference between the means of less and more frequently flying passengers regarding safety perception about Turkish airports $(\mathrm{p}<0.05)$. It is evident from the means of the flight frequency groups that the less flying group feels safer than more flying passengers.

\subsection{Fairness on Safety Perception}

Table (4) indicates that there is a significant difference among three groups of passengers with different fairness perception degrees regarding safety perception $[\mathrm{F}=41.75 ; \mathrm{P}=0.00<0.05]$.

Table (5) shows that there is a significant difference among all of the three groups regarding safety perception. Passengers finding the treatment highly fair are the group that has the most positive safety perception scores. The safety perception scores in the groups decrease as the fairness perception degree of passengers decrease.

\subsection{Satisfaction on Safety Perception}

Table (6) indicates that there is a significant difference among three groups of passengers with different satisfaction degrees regarding safety perception $[\mathrm{F}=136.13 ; \mathrm{P}=0.00<0.05]$.

Table (7) shows that there is a significant difference among all of the three groups regarding safety perception. Passenger group highly satisfied with the treatment at airports has the most positive safety perception scores. The safety perception scores in the groups decrease as the satisfaction degree of passengers decrease.

On the other hand, age, gender, educational level, average monthly income and, flight objective were the variables that indicated no meaningful association with passenger safety perception in Turkish airports at significance level 0.05 .

Results of analyses removed the independent variables that have no effects from the model. The modified final model is as below in Figure 2.

\section{Conclusions}

European tourists feel less safe than Turkish passengers. This may be due to a natural tendency that foreign tourists feel less safe than the natives. Another finding regarding the results was that people flying more frequently feel less safe. The volume of experience with other airports in other countries gives opportunity to make comparisons on safety consideration. That is why they may have greater expectations that are hardly met.

Another major finding was that passengers who find the treatments at airport unfair are likely to feel less safe. This may be the evidence that unfair service delivery in an environment may lead people to feel less safe. Findings of the study ascertained that people with high safety feelings had high satisfaction from the services in the airport. The reciprocal relationship between safety and satisfaction was testified with the results.

It was found that age, gender, educational level, average monthly income and flight objective of the passenger 
had no association with safety perception. It is a fact that safety perception of an individual has numerous antecedents. But within the limitation of this study's customer point of view, the future research should survey for travellers' some other characteristics such as socio-economic level, attitudes towards technology as the factors that have association with safety perception.

\section{References}

Abeyratne, R. (2001). Ethical and moral considerations of airline management. Journal of Air Transport Management, 7, 339-348.

Airport Voluntary Commitment on Air Passenger Service. (2007). [Online] Available: http://www.aci-europe.org (01.09.2007)

Anderson, E. W., Fornell, C., \& Lehrmann, D. R. (1994). Customer satisfaction, market share and profitability: Findings from Sweden. Journal of Marketing, 58, 3, 53-66.

Austin, W., McGinn, N.C., \& Susmilch, C. (1980). Internal standards revisited: Effects of social comparisons and expectancies on judgments of fairness and satisfaction. Journal of Experimental Social Psychology, 16.

Bassi, F., \& Guido, G. (2006). Measuring customer satisfaction: From product performance to consumption experience. Journal of Consumer Satisfaction, Dissatisfaction and Complaining Behavior, 19, 76-88.

Blum, U. C. H., \& Feltes, T. (1987). The long term development of criminal offenses in the Federal Republic of Germany, 1985-2030. Journal of Contemporary Criminal Justice, 3, 70-81.

Brunt, P., Mawby, R., \& Hambly, Z. (2000). Tourist victimisation and the fear of crime on holiday. Tourism Management, 21, 417-424.

Carr, N. (2001). An exploratory study of gendered differences in young tourists perceptin of danger within London. Tourism Management, 22, 565-570.

Colquitt, J. A. (2001). On the dimensionality of organizational justice: A construct validation of a measure. Journal of Applied Psychology, 86, 386-400.

Correia, A. R., \& Wirasinghe, S. C. (2007). Development of level of service standards for airport facilities: Application to Sao Paulo international airport. Journal of Air Transport Management, 13, 97-103.

Fodness, D., \& Murray, B. (2007). Passengers' expectations of airport service quality. Journal of Services Marketing, 21, 7, 492-506.

George, R. (2003). Tourist's perceptions of safety and security while visiting Cape Town. Tourism Management, 24, 575-585.

Gkritza, K., D. Niemeier, Mannering, F.L. (2006). Airport security screening and changing passenger satisfaction: An exploratory assessment. Journal of Air Transport Management, 12, 213-219.

Goodrich, J. N. (2002). September 11, 2001 attack on America: A record of the immediate impacts and reactions in the USA travel and tourism industry. Tourism Management, 23, 573-580.

Goodwin, C., \& Ross, I. (1992). Consumer responses to service failure: Influence of procedural and interactional fairness perception. Journal of Business Research, 25, 149-163.

Kinnaird, V. (1996). Understanding tourism processes: A gender-aware framework. Tourism Management, 17, 2 , 95-102.

Law, R. (2006). The perceived impact of risks on travel decisions. International Journal Of Tourism Research, 8 , 289-300.

Mansfeld, Y. (1992). Group-differentiated perceptions of social impacts related to tourism development. Professional Geographer, 44, 4, 377-392.

Martin-Cejas, R. R. (2006). Tourism service quality begins at the airport. Tourism Management, 27, 874-877.

Mehta, A., \& Bondi, L. (1999). Embodied discourse: On gender and fear of violence. Gender, Place \& Culture: A Journal of Feminist Geography, 6, 1, 67-84.

Messick, D.M., and Sentis K. (1983). Fairness, preference, and fairness biases, in Equity Theory, David M. Messick and Karen S. Cook (Eds), New York, Praeger, pp. 61-94.

Milman, A., Jones, F., \& Bach, S. (1999). The impact of security devices on tourists' perceived safety: The Central Florida example. Journal of Hospitality \& Tourism Research, 23, 371-386. 
Nebeker, D., Busso, L., Philipp, D., Werenfels, P.D., Diallo, H., Czekajewski, A., and Ferdman, B. (2001). Airline station performance as a function of employee satisfaction. Journal of Quality Management, 6, 29-45.

Nunnally, J. C. (1978). Psychometric Theory, 2th Edition. McGraw-Hill, New York.

OECD Prison population rate. (2009). [Online] Available: http://www.oecd.org/dataoecd/26/40/38785295.htm (01.06.2009)

Oliver, R.L. (1997). Satisfaction: A behavioral perspective on the consumer. New York: McGraw-Hill.

Paternoster, J. (2008). Excellent airport customer service meets successful branding strategy. Airport Management, 2, 3, 218-226.

Rountree, P. W. (1996). Perceived risk versus fear of crime: Empirical evidence of conceptually distinct reactions in survey data. Social Forces, 74, 4, 1353-1376.

Russell, P. A., \& Preston, F. W. (2004). Airline security after the event: Unintended consequences and illusions. The American Behavioral Scientist, 47, 11, 1419-1427.

Sindhav, B., Holland, J., Rodie, A. R., Adidam, P. T., \& Pol, L. G. (2006). The impact of perceived fairness on satisfaction: Are airport security measures fair? Does it matter?. Journal of Marketing Theory and Practice, 14, 4, 323-334.

Smith, S. (1987). Fear of crime: Beyond a geography of deviance. Progress in Human Geography, 11, 1, 1-23.

Sönmez, F. S., \& Graefe A. R. (1998). Influence of terrorism risk on foreign tourism decision. Annals of Tourism Research, 25, 1, 112-144.

Swan, J.E., \& Oliver, R.L. (1991). An applied analysis of buyer equity perceptions and satisfaction with automobile salespeople. Journal of Personal Selling and Sales Management, 11, 15-26.

Szymanski, D.M., \& Henard, D.H. (2001). Customer satisfaction: A meta-analysis of the empirical evidence. Journal of the Academy of Marketing Science, 29, 16-35.

Wilkinson, S. (1994). The social construction of heterosexuality. Journal of Gender Studies, 3, 3, 307-316.

Yoda, Takuro. (2007). Effect of unfairness on customer satisfaction: New insights into customer retention. Innovative Marketing, 3, 1, 44-55.

Yuksel, A., \& Rimmington, M. (1998). Customer-Satisfaction measurement: Performance Counts. Cornell Hotel and Restaurant Administration Quarterly, 39, 6, 60-70. 
Table 1. Demographic Characteristics of Sample

\begin{tabular}{|l|c|c|}
\hline & $\underline{\mathbf{N}}$ & $\underline{\mathbf{\%}}$ \\
\hline Age & 531 & 32.9 \\
\hline $0-30$ & 552 & 34.2 \\
$31-45$ & 388 & 24.1 \\
\hline $46-100$ & 658 & 44.2 \\
\hline Gender & 831 & 55.8 \\
\hline Female & & \\
Male & 75 & 4.7 \\
\hline Educational level & 563 & 34.9 \\
\hline Primary & 814 & 50.5 \\
High school & & \\
University and higher & 313 & 19.4 \\
\hline Average monthly income & 368 & 22.8 \\
0-1500 & 320 & 19.9 \\
1501-3000 & & \\
3001-more & 595 & 36.9 \\
\hline Nationality & 911 & 56.5 \\
\hline European & & \\
Turkish & 675 & 41.9 \\
\hline Flight frequency in a year & 544 & 33.7 \\
\hline 0-2 times & & \\
3- more times & 359 & 22.3 \\
\hline Flight objective & 104 & 6.5 \\
\hline Business & 695 & 43.1 \\
Education & 96 & 6.0 \\
Tourism & 190 & 11.8 \\
Health & 357 & 22.1 \\
Other & 732 & 45.4 \\
\hline Fairness perception & 304 & 18.9 \\
\hline Unfair & 479 & 29.7 \\
Fair & 498 & 30.9 \\
Highly fair & & 26.1 \\
\hline Satisfaction level & & \\
\hline Unsatisfied & & \\
Satisfied & & \\
Highly satisfied & & \\
\hline
\end{tabular}

Table 2. Nationalities on Safety Perceptions

\begin{tabular}{|l|l|l|l|l|l|l|}
\hline \multirow{2}{*}{} & \multicolumn{4}{|c|}{ Curopean passengers } & \multicolumn{2}{l|}{ Turkish passengers } \\
\cline { 2 - 7 } & \multicolumn{2}{|c|}{} & \multicolumn{2}{l|}{ stionalities } \\
\cline { 2 - 7 } & $\mathrm{t}$ & sig. (2-t.) & mean & std. dev. & mean & std. dev. \\
\hline Safety Perception & -4.63 & 0.00 & 4.86 & 0.88 & 5.09 & 1.01 \\
\hline
\end{tabular}

Table 3. Flight Frequencies on Safety Perceptions

\begin{tabular}{|l|l|l|l|l|l|l|}
\hline \multirow{2}{*}{} & \multicolumn{4}{|c}{ 0-2 times } & \multicolumn{3}{c|}{ 3-more times } \\
\cline { 2 - 7 } & \multicolumn{3}{|c|}{} & \multicolumn{3}{|c|}{ Fight Frequency } \\
\cline { 2 - 7 } & $\mathrm{t}$ & sig. (2-t.) & mean & std. dev. & mean & std. dev. \\
\hline Safety Perception & 1.99 & 0.04 & 5.09 & 0.91 & 4.98 & 0.96 \\
\hline
\end{tabular}


Table 4. Fairness on Safety Perception

\begin{tabular}{|c|c|c|c|c|}
\hline \multicolumn{5}{|l|}{ ANOVA } \\
\hline & & mean & $\mathbf{F}$ & Sig. \\
\hline \multirow{4}{*}{$\begin{array}{l}\text { Safety } \\
\text { Perception }\end{array}$} & Unfair & 4.65 & \multirow[b]{4}{*}{41.75} & \multirow[b]{4}{*}{0.00} \\
\hline & Fair & 5.05 & & \\
\hline & Highly fair & 5.31 & & \\
\hline & & & & \\
\hline
\end{tabular}

Table 5. Multiple Comparisons

\begin{tabular}{|l|l|l|l|}
\hline \multicolumn{3}{|c|}{ Post Hoc (Tukey) } \\
\hline $\begin{array}{l}\text { Dependent } \\
\text { variable }\end{array}$ & \multirow{2}{*}{ (I) class } & $(\mathbf{J})$ class & Sig. \\
\hline Safety perception & Unfair & Fair & 0.00 \\
\cline { 3 - 4 } & & Highly fair & 0.00 \\
\cline { 3 - 4 } & Fair & Unfair & 0.00 \\
\cline { 3 - 4 } & & Highly fair & 0.00 \\
\cline { 3 - 4 } & Highly fair & Unfair & 0.00 \\
\cline { 3 - 4 } & & Fair & 0.00 \\
\hline
\end{tabular}

Table 6. Satisfaction on Safety Perception

\begin{tabular}{|c|c|c|c|c|}
\hline \multicolumn{5}{|l|}{ ANOVA } \\
\hline & & mean & $\mathbf{F}$ & Sig. \\
\hline \multirow{4}{*}{$\begin{array}{l}\text { Safety } \\
\text { Perception }\end{array}$} & Unsatisfied & 4.51 & \multirow[b]{4}{*}{136.13} & \multirow[b]{4}{*}{0.00} \\
\hline & Satisfied & 5.04 & & \\
\hline & Highly satisfied & 5.50 & & \\
\hline & & & & \\
\hline
\end{tabular}

Table 7. Multiple Comparisons

\begin{tabular}{|l|l|l|l|}
\hline \multicolumn{3}{|c|}{ Post Hoc (Games-Howell) } \\
\hline $\begin{array}{l}\text { Dependent } \\
\text { variable }\end{array}$ & (I) class & $\mathbf{( J )}$ class & Sig. \\
\hline $\begin{array}{l}\text { Safety } \\
\text { perception }\end{array}$ & Unsatisfied & Satisfied & 0.00 \\
\cline { 3 - 4 } & Satisfied & Highly satisfied & 0.00 \\
\cline { 3 - 4 } & & Unsatisfied & 0.00 \\
\cline { 3 - 4 } & Highly satisfied & Unsatisfied & 0.00 \\
\cline { 3 - 4 } & & Satisfied & 0.00 \\
\hline
\end{tabular}



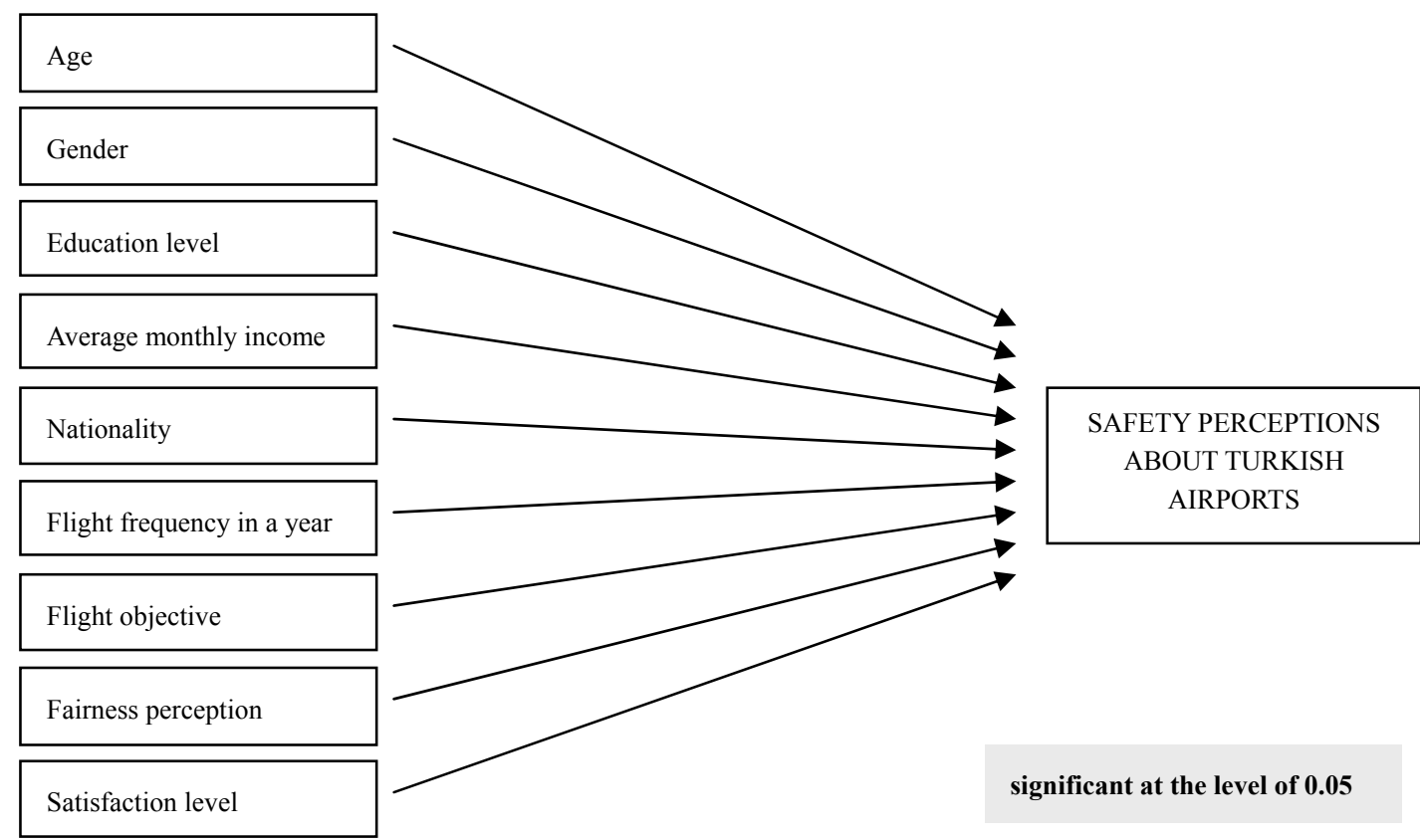

Figure 1. Proposed Model on European and Turkish Passengers' Safety Perceptions About Turkish Airports
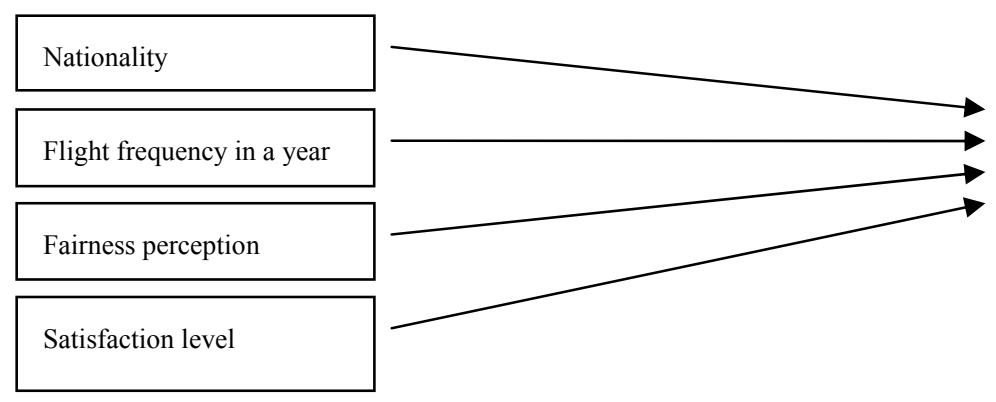

significant at the level of 0.05
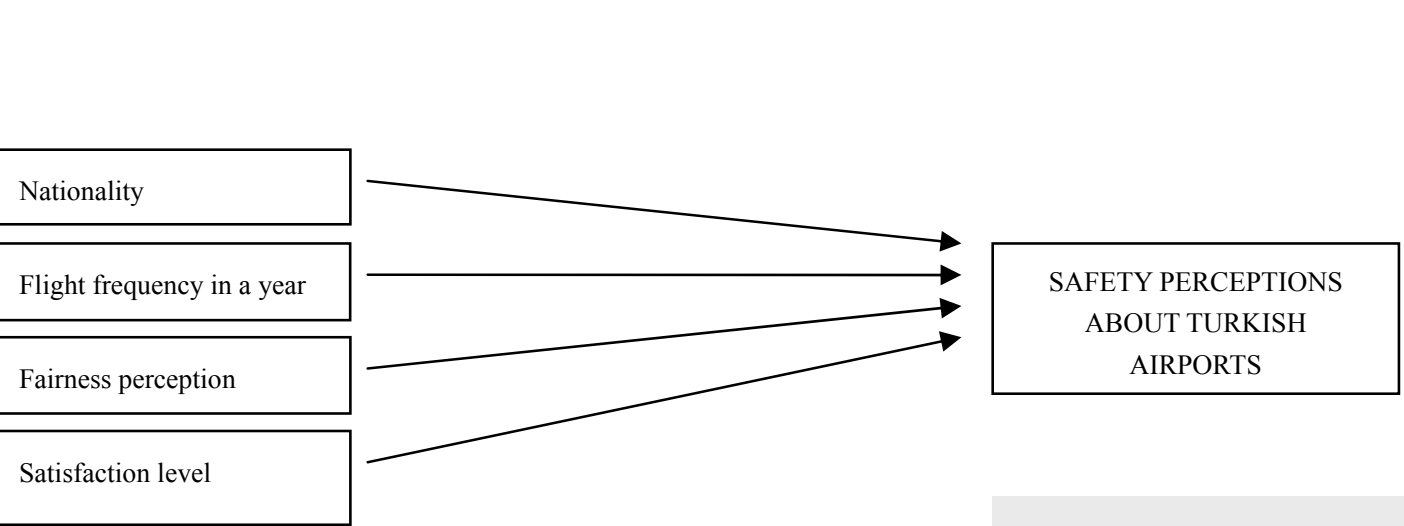

significant at the level of 0.05

Figure 2. Final Model on European and Turkish Passengers' Safety Perceptions About Turkish Airports 